\title{
Biocontrol of charcoal-rot of sorghum by actinomycetes isolated from herbal vermicompost
}

\author{
Subramaniam Gopalakrishnan*, Bandru Keerthi Kiran, Pagidi Humayun, Meesala Sree Vidya, \\ Kanala Deepthi, Simi Jacob, Srinivas Vadlamudi, Gottumukkala Alekhya and Om Rupela
}

\author{
Research Program-Grain Legumes, International Crops Research Institute for the Semi-Arid Tropics (ICRISAT), \\ Patancheru 502 324, Andhra Pradesh, India.
}

Accepted 17 November, 2011

\begin{abstract}
A total of 137 actinomycetes, isolated from 25 different herbal vermicomposts, were characterized for their antagonistic potential against Macrophomina phaseolina by dual-culture assay. Of them, eight most promising isolates (CAl-17, CAl-21, CAI-26, CAl-68, CAl-78, KAI-26, KAI-27 and MMA-32) were characterized for the production of siderophore, chitinase, protease, hydrocyanic acid (HCN), indole acetic acid (IAA) and further evaluated for their antagonistic potential against $M$. phaseolina by blotterpaper assay and in greenhouse. All the eight isolates produced HCN and IAA, seven produced siderophore (except CAl-78) and protease (except KAl-27) and four produced chitinase (CAI-26, KAI-26, KAI-27 and MMA-32). In the blotter-paper assay, no charcoal-rot infection was observed in KAl-26 and KAI-27-treated sorghum roots, indicating complete inhibition of the pathogen, while the other isolates showed 47 to $88 \%$ lesser charcoal-rot infection compared to the control. In the antifungal activity test against $M$. phaseolina (in greenhouse on sorghum), all the isolates increased in shoot dry mass by 28 to $53 \%$ and root dry mass by 5 to $21 \%$, over the control. In order to confirm the plant growth promoting (PGP) traits of the isolates, the green house experiment was repeated, but in the absence of $M$. phaseolina. The results further confirmed the PGP traits of the isolates as evidenced by 15 to $34 \%$ increase in shoot dry mass on six isolates (except CAI-26 and KAI-27), 14 to $57 \%$ increase in root dry mass on five isolates (except CAI-68, KAl-26 and KAl-27), 17 to $60 \%$ increase in root length on five isolates (except CAl-17, CAI-21 and CAI-68) and 10 to $64 \%$ increase in root volume on six isolates (except CAl-17 and CAI-68). Culture filtrate of three potential actinomycetes (CAI-21, CAl-26 and MMA32 ) at $0.5 \%$ inhibited the growth of $M$. phaseolina, indicating that the metabolites of these actinomycetes were responsible for the inhibition. The sequences of 16S rDNA gene of the isolates matched with Streptomyces but with different species in BLAST analysis. This study indicates that the selected actinomycetes have the potential for PGP and control of charcoal-rot disease in sorghum.
\end{abstract}

Key words: Antagonistic actinomycetes, biocontrol, charcoal-rot, Macrophomina phaseolina.

\section{INTRODUCTION}

Charcoal-rot of sorghum (Sorghum bicolor) caused by Macrophomina phaseolina (Tassi) Goid. is endemic to tropical and temperate regions of the world (Wyllie,

*Corresponding author. E-mail: s.gopalakrishnan@cgiar.org. Tel: +91403071 3610. Fax: +914030713074.

Abbreviations: HCN, Hydrocyanic acid; IAA, indole acetic acid; PGP, plant growth promoting.
1998). Significant losses of yield (up to 64\%) have been observed in India under conditions favoring the incidence of the disease in post-rainy sorghum, occupying more than 5 million ha in Maharashtra, Karnataka and Andhra Pradesh (Das et al., 2008). In addition to severely damaging the crop, the pathogen also produces a toxin called "phaseolinone" in the diseased stalk that causes anemia in mice (Bhattacharya et al., 1994). Management of charcoal rot of sorghum is difficult, as no single control measure is fully effective. Actinomycetes are a group of Gram-positive bacteria, with high $G+C$ content 
belonging to the order Actinomycetales, which form branched mycelium and hence have sometimes been classified as fungi imperfecti. These are found most commonly in soil, compost, fresh and marine water and play an important role in the decomposition of organic materials and produce secondary metabolites of commercial interest. The biological degradation and conversion of agricultural wastes or herbals by earthworms and microorganisms, called vermicomposting, is becoming a favored method of recycling wastes (Edwards, 1998).

One of the advantages of using earthworms in composting is that it creates aerobic conditions and release coelomic fluids in the decaying biomass, which contains factor(s) that kills pathogens such as Salmonella, Serratia marcesens and Escherichia coli (Prabha, 2009). Application of vermicompost prepared from the herbals not only benefits crop plants as it contains beneficial microorganisms, that help the plants to mobilize and acquire nutrients, but also promotes plant growth and inhibits many plant pathogenic microorganisms (Postma et al., 2003; Suthar et al., 2005; Perner et al., 2006; Nath and Singh, 2009). Efficacy of Jatropha, Annona and Parthenium vermiwash was shown to inhibit $M$. phaseolina, Sclerotium rolfsii and FOC (Gopalakrishnan et al., 2010). Hence, in the present investigation, several herbal vermicomposts were screened for actinomycetes that contain antagonistic potential against charcoal-rot in sorghum. The objective of this study was to isolate, characterize and evaluate the actinomycetes isolated from vermicomposts for their ability to suppress $M$. phaseolina.

\section{MATERIALS AND METHODS}

\section{Preparation of herbal vermicompost samples}

Foliages of 25 different botanicals (Jatropha curcas, Annona squamosa, Parthenium hysterophorus, Oryza sativa, Gliricidia sepium, Adhatoda vasica, Azadirachta indica, Capsicum annuum, Calotropis gigantea, Calotropis procera, Datura metal, Allium sativum, Zingiber officinale, Ipomoea batatas, Momordica charantia, Moringa oleifera, Argyranthemum frutescens, Nerium indicum, Allium cepa, Curcuma aromatica, Pongamia pinnata, Abacopteris multilineata, Nicotiana tabacum, Tridax procumbens and Vitex negundo) were collected from the International Crops Research Institute for the Semi-Arid Tropics (ICRISAT) farm and air-dried at room temperature $\left(30 \pm 2^{\circ} \mathrm{C}\right)$. The container for vermicomposting was constructed by cutting a $200 \mathrm{~L}$ plastic barrel into two halves. A metal grill was placed at the bottom of the barrel $(10 \mathrm{~cm}$ clearance from the base [floor] of the barrel), and the air-dried foliages of the herbals (bedding material) were composted on top of the grill with earthworms (Eisenia foetida). The bedding material was moistened with water before being added to the barrel. The barrel was covered with a lid to keep the moisture intact and to avoid light as earthworms grow well in moist environment and darkness. A layer of foliage was added once a week as feed for the earthworms. The whole set-up was left for 2 months until all the foliages of the herbals were digested. When the herbal compost was ready, about $100 \mathrm{~g}$ of the sample was collected and stored in a refrigerator at $4^{\circ} \mathrm{C}$ for further studies.
Actinomycetes, bacterial and fungal population in the herbal vermicompost

Ten grams of herbal vermicompost from each sample were separately suspended in $90 \mathrm{ml}$ of sterilized physiological saline $(0.85 \%$ of $\mathrm{NaCl})$ in a flask and placed on an orbital shaker (at 100 $\mathrm{rpm})$ at room temperature $\left(28 \pm 2^{\circ} \mathrm{C}\right)$ for $1 \mathrm{~h}$. At the end of shaking, the vermicompost samples were serially diluted up to $10^{6}$ dilutions with physiological saline. Dilutions $10^{4}$ to $10^{6}$ were plated for enumerating actinomycetes (on starch casein agar; SCA) and bacteria (on Luria agar), while $10^{2}$ to $10^{4}$ were plated for fungal colonies (on potato dextrose agar) by spread plate technique and incubated at $28 \pm 2{ }^{\circ} \mathrm{C}$ for four days. Bacterial colonies were enumerated at the end of $24 \mathrm{~h}$ incubation, while fungal and actinomycetes were enumerated at the end of 72 and $96 \mathrm{~h}$, respectively. The most prominent actinomycete colonies (the ones which were found abundantly in the plate, produced pigments and inhibited the adjacent colonies) were isolated and maintained on SCA slants at $4^{\circ} \mathrm{C}$ for further studies.

\section{In vitro antifungal activity}

Actinomycete isolates were evaluated for their antifungal activity against $M$. phaseolina by dual-culture assay. $M$. phaseolina was acquired from the Directorate of Sorghum Research, Hyderabad, India. A fungal disk ( $M$. phaseolina) of $6 \mathrm{~mm}$ diameter was placed on one edge (1 $\mathrm{cm}$ from the corner) of the glucose casamino acid yeast extract (GCY) agar plate and the actinomycete isolate was streaked on the other edge of the plate $(1 \mathrm{~cm}$ from the corner), followed by incubation at $28 \pm 2^{\circ} \mathrm{C}$ for four days or until the pathogen covered the entire plate in the control plate. Inhibition of fungal mycelium (halo zone) around the actinomycete colony was noted as positive and the inhibition zone measured.

\section{In vitro plant growth-promoting attributes of the actinomycetes isolates}

\section{Siderophore production}

Siderophore production was determined according to the methodology described by Schwyn and Neilands (1987). Actinomycetes were streaked on Chrome Azurol S (CAS) agar media and incubated at $28 \pm 2{ }^{\circ} \mathrm{C}$ for four days. When the actinomycetes consume iron present in the blue-colored CAS media, orange halos are produced around the colonies, which indicate the presence of siderophores. Observations were recorded on a 0 to 4 rating scale as follows: $0=$ no change; $1=$ positive (slight halo); 2 = halo zone of 1 to $3 \mathrm{~mm} ; 3$ = halo zone of 4 to $6 \mathrm{~mm}$ and $4=$ halo zone of $7 \mathrm{~mm}$ and above.

\section{Chitinase production}

Colloidal chitin was prepared freshly and used in the Chitin agar as per the standard protocols of Hirano and Nagao (1988). Actinomycetes were streaked on Chitin agar and incubated at $28 \pm 2{ }^{\circ} \mathrm{C}$ for four days. At the end of the incubation, the plates were observed for halo zones around the colonies, which indicate the production of chitinase. Observations were recorded on a 0 to 4 rating scale as follows: $0=$ no change; 1 = positive (slight halo); $2=$ halo zone of 1 to $3 \mathrm{~mm} ; 3$ = halo zone of 4 to $6 \mathrm{~mm}$ and 4 = halo zone of $7 \mathrm{~mm}$ and above.

\section{Protease production}

It was done as per the protocols of Bhattacharya et al. (2009). 
Actinomycetes were streaked on Casein agar and incubated at $28 \pm 2{ }^{\circ} \mathrm{C}$ for four days. At the end of the incubation, the plates were observed for halo zones around the colonies, which indicate the production of protease. Observations were recorded on a 0 to 4 rating scale as follows: $0=$ no change; 1 = positive (slight halo); $2=$ halo zone of 1 to $3 \mathrm{~mm} ; 3=$ halo zone of 4 to $6 \mathrm{~mm}$ and $4=$ halo zone of $7 \mathrm{~mm}$ and above.

\section{Hydrocyanic acid ( $\mathrm{HCN})$ production}

$\mathrm{HCN}$ was estimated qualitatively by sulfocyanate colorimetric method (Lorck, 1948). The actinomycetes were grown on Bennett agar amended with glycine $\left(4.4 \mathrm{~g} \mathrm{I}^{-1}\right)$. One sheet of Whatman filter paper no. 1 ( $8 \mathrm{~cm}$ diameter) was soaked in 1\% picric acid (in 10\% sodium carbonate; filter paper and picric acid were sterilized separately) for a minute and stuck underneath the Petri dish lids. The plates were sealed with parafilm and incubated at $28 \pm 2^{\circ} \mathrm{C}$ for four days. Development of reddish brown color on the filter paper indicated positive for HCN production. Observations were recorded on a 0 to 3 rating scale (they were rated based on the intensity of the reddish brown color) as follows: $0=$ no color change; $1=$ light reddish brown; 2 = medium reddish brown and $3=$ dark reddish brown.

\section{Indole acetic acid (IAA) production}

It was done as per the protocols of Patten and Glick (1996). The actinomycetes were grown in Starch casein broth supplemented with L-tryptophan $\left(1 \mathrm{\mu g} \mathrm{ml}^{-1}\right)$ for four days. At the end of the incubation, the cultures were centrifuged at $10,000 \times g$ for $10 \mathrm{~min}$, and the supernatants collected. One $\mathrm{ml}$ of this culture filtrate was allowed to react with $2 \mathrm{ml}$ of Salkowsky reagent $(1 \mathrm{ml}$ of $0.5 \mathrm{M}$ $\mathrm{FeCl}_{3}$ in $50 \mathrm{ml}$ of $35 \% \mathrm{HClO}_{4}$ ) at $28 \pm 2{ }^{\circ} \mathrm{C}$ for $30 \mathrm{~min}$. At the end of the incubation, development of pink color indicated the presence of IAA. Quantification of IAA was done my measuring the absorbance in a spectrophotometer at $530 \mathrm{~nm}$. A standard curve was plotted to quantify the IAA $\left(\mu \mathrm{g} \mathrm{ml}^{-1}\right)$ present in the culture filtrate.

\section{In vivo antifungal activity by blotter paper assay}

Determination of in vivo antifungal activity of the eight most potential actinomycetes against $M$. phaseolina was done by blotter paper assay technique (Nene et al., 1981). Inoculum of $M$. phaseolina was prepared by homogenizing (with a tissuemizer; Techmar type $\mathrm{T} 25$, Japan) a 5-day-old $M$. phaseolina culture grown on potato dextrose broth $(\mathrm{PDB})$ at $28 \pm 2{ }^{\circ} \mathrm{C}$. Two-week-old seedlings of sorghum (raised in sterilized vermiculite in $12 \mathrm{~cm}$ pots; variety R16- susceptible to charcoal-rot) were dipped in the inoculum of $M$. phaseolina for $30 \mathrm{~min}$ and placed side by side on a blotter paper $(45 \times 25 \mathrm{~cm}$ with one fold), so that only the roots were covered. Actinomycete isolates (CAl-17, CAI-21, CAl-26, CAl-68, CAl-78, KAl-26, KAl-27 and MMA-32) were inoculated (5 ml plant ${ }^{-1}$ ) separately into plants.

Fifteen plants per replicate and three replications were made for each actinomycete isolate. Positive and negative controls were made by inoculating the plants only with $M$. phaseolina and sterile water, respectively. The blotter paper was kept moist all the time with sterilized water and incubated at $28 \pm 2^{\circ} \mathrm{C}$ for 8 days with a 12$\mathrm{h}$ day length provided by fluorescent lights $\left(120 \mu \mathrm{mol} \mathrm{m} \mathrm{m}^{-2} \mathrm{~s}^{-1}\right)$. At the end of the incubation, the disease symptoms of the charcoal-rot (black-colored microselerotia infection on the root surface) were recorded on a 0 to 4 rating scale (0 represents no visible charcoalrot symptom, while 4 represents maximum disease symptoms), and the percentage of infected roots in actinomycete inoculated treatments compared with the control was calculated.

\section{In vivo antifungal activity in a greenhouse}

Eight potential antagonistic actinomycete isolates (CAI-17, CAI-21, CAl-26, CAl-68, CAl-78, KAl-26, KAl-27 and MMA-32) were evaluated in greenhouse for their antagonistic potential against $M$. phaseolina. A total of 9 treatments (eight actinomycetes $+M$. phaseolina inoculated- positive control) were made with six replications. M. phaseolina inoculum was mass multiplied on sorghum grains (variety R16) as per the protocols of Gupta et al. (2002). Pot mixture $(800 \mathrm{~g})$ was prepared by mixing red soil, sand and farm yard manure at 3:2:2 and filled in 8" plastic pots followed by inoculation with $M$. phaseolina inoculum (20\% of pot weight, 200 $\left.\mathrm{g} \mathrm{pot}^{-1}\right)$. Inoculum was mixed thoroughly with the pot mixture. Water $(100 \mathrm{ml})$ was added to each pot to wet the potting mixture and the pots were covered with polythene sheets. The whole set-up was incubated at $32 \pm 2^{\circ} \mathrm{C}$ in green house for 15 days for charcoal-rot symptoms to develop.

Two weeks later, sorghum seeds (variety R16) were surfacesterilized with sodium hypochlorite (2.5\%) for $5 \mathrm{~min}$ and rinsed eight times with sterilized water before allowing it to sprout in a Petri plate overnight. The sprouted seeds were transferred into test actinomycete isolates (grown in Starch casein broth separately) for an hour before being sown in the pots $(6$ seeds/pot but thinned to 3 after 1 week). Booster doses of actinomycete isolates $(5 \mathrm{ml}$ per

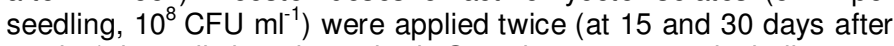
sowing) by soil drench method. Growth parameters including root length, root dry weight, shoot dry weight, shoot root ratio, percentage of root and shoot dry weight increase over the control and the disease incidence were determined at day 60 after sowing.

\section{In vivo PGP activity in a greenhouse}

For evaluating the PGP potential of the eight actinomycete isolates as potential biocontrol agents against $M$. phaseolina actinomycete isolates, the previously explained greenhouse experiment was repeated without applying $M$. phaseolina. However, one new treatment was included in which only water was added and the positive control (only $M$. phaseolina inoculated) was removed. A total of nine treatments (eight antagonistic actinomycetes + negative [water] control) were made with six replications. Growth parameters including root length, root volume, root dry weight, shoot dry weight, shoot root ratio and \% root and shoot dry weight and length increase over the control were determined at day 60, after sowing.

\section{Effect of the culture filtrates of actinomycetes on fungal pathogens}

Culture filtrates $(1 \mathrm{~L})$ of three actinomycetes (CAl-21, CAI-26 and MMA-32) were prepared from 5-day-old cultures grown in Starch casein broth by collecting the supernatants after centrifuging the cultures for $20 \mathrm{~min}$ at $10,000 \times \mathrm{g}$. After adjusting the $\mathrm{pH}$ to 3.0 , the supernatants were partitioned three times against ethyl acetate (EtOAc) resulting in organic and aqueous fractions. The organic fraction was combined, dried over anhydrous sodium sulphate and the EtOAc removed by film evaporation on a rotary evaporator (BUCHI V-850, Switzerland) at $35^{\circ} \mathrm{C}$. The residues were dissolved in $10 \mathrm{ml}$ of methanol and stored in a freezer at $-20^{\circ} \mathrm{C}$. The aqueous fraction was combined, evaporated on a rotary evaporator at $35^{\circ} \mathrm{C}$ and dissolved in minimal volumes of methanol $(10 \mathrm{ml})$. Both organic as well as aqueous fractions were evaluated for their antagonistic potential against $M$. phaseolina. 
Table 1. Microbial population* (actinomycetes, bacteria and fungal), diversity and $\mathrm{pH}$ of 25 different herbal vermicomposts used in this study.

\begin{tabular}{|c|c|c|c|c|c|c|c|c|}
\hline \multirow{2}{*}{ Common name } & \multirow{2}{*}{ Scientific name } & \multicolumn{2}{|c|}{ Actinomycetes } & \multicolumn{2}{|c|}{ Bacteria } & \multicolumn{2}{|c|}{ Fungi } & \multirow{2}{*}{$\mathrm{pH}$} \\
\hline & & Count & Diversity & Count & Division & Count & Division & \\
\hline Rice straw & Oryza sativa & 7.41 & 6 & 8.67 & 14 & 6.63 & 3 & 7.01 \\
\hline Gliricidia foliage & Gliricidia sepium & 7.53 & 6 & 8.92 & 13 & 6.93 & 7 & 8.13 \\
\hline Neem foliage & Azadirchta indica & 7.51 & 8 & 9.26 & 17 & 6.97 & 5 & 7.76 \\
\hline Adhatoda foliage & Adhatoda vasica & 7.12 & 4 & 8.89 & 12 & 6.52 & 6 & 8.27 \\
\hline Annona foliage & Annona squamosa & 7.74 & 7 & 9.31 & 8 & 7.05 & 5 & 7.94 \\
\hline Chilli foliage & Capsicum annuum & 6.83 & 2 & 8.88 & 11 & 6.57 & 7 & 8.14 \\
\hline Calotrophis foliage & Calotrophis gigantean & 7.04 & 3 & 8.99 & 10 & 6.64 & 6 & 8.06 \\
\hline Chrysanthemum foliage & Chrysanthemum morifolium & 7.4 & 12 & 7.4 & 12 & 6.55 & 6 & 7.63 \\
\hline Datura foliage & Datura metal & 0 & 0 & 8.78 & 13 & 6.84 & 3 & 7.7 \\
\hline Garlic foliage & Allium sativum & 7.12 & 4 & 8.59 & 10 & 7.05 & 8 & 8.18 \\
\hline Ginger foliage & Zingiber officinale & 7.46 & 7 & 8.82 & 11 & 7.13 & 6 & 8.79 \\
\hline Sweet potoato foliage & Ipomoea batatas & 7.27 & 6 & 8.73 & 10 & 6.27 & 4 & 7.8 \\
\hline Jatropha foliage & Jatropha curcas & 6.82 & 2 & 8.76 & 10 & 6.95 & 7 & 8.05 \\
\hline Jatropha seed & Jatropha curcas & 6.88 & 1 & 8.7 & 10 & 6.99 & 6 & 7.42 \\
\hline Bitter gueard foliage & Momordica charantia & 7.29 & 3 & 8.74 & 11 & 6.74 & 6 & 8.14 \\
\hline Drum stick foliage & Moringa oleifera & 6.68 & 2 & 8.73 & 9 & 6.59 & 7 & 7.78 \\
\hline Oleander foliage & Nerium indicum & 7.25 & 5 & 8.8 & 15 & 6.7 & 4 & 8.01 \\
\hline Onion foliage & Allium cepa & 6.33 & 1 & 8.59 & 11 & 6.65 & 5 & 8.73 \\
\hline Parthenium foliage & Parthenium hysterophorus & 7.51 & 8 & 8.8 & 10 & 6.81 & 8 & 8.03 \\
\hline Wild turmeric foliage & Curcuma aromatica & 7.2 & 5 & 8.77 & 13 & 7.06 & 6 & 9.07 \\
\hline Pongamia foliage & Pongamia pinnata & 7.4 & 6 & 8.73 & 7 & 7.33 & 9 & 7.32 \\
\hline Yellow oleander foliage & Thevetia peruviana & 7.17 & 6 & 8.65 & 11 & 6.86 & 3 & 8.02 \\
\hline Tobacco foliage & Nicotiana tabacum & 2 & 2 & 8.74 & 8 & 7 & 7 & 8.37 \\
\hline Tridax foliage & Tridax procumbens & 6.83 & 3 & 8.57 & 7 & 6.83 & 7 & 8.32 \\
\hline Vitex foliage & Vitex negundo & 7.12 & 2 & 8.91 & 6 & 6.99 & 4 & 7.49 \\
\hline
\end{tabular}

${ }^{*}$ Microbial populations were expressed in $\log _{10}$ values; Div = diversity.

A loop full of M. phaseolina were inoculated on the center of a PDA plate and incubated at $28^{\circ} \mathrm{C}$ for 4 days. Upon its growing, one disc of $6 \mathrm{~mm}$ diameter was perforated from the growing mycelia using a sterile borer and inoculated into a flask containing $20 \mathrm{ml}$ of PDB. Both organic and aqueous fraction samples $(100 \mu \mathrm{l})$ were inoculated separately into the aforementioned flask, whereas in the control $100 \mu \mathrm{l}$ of methanol was added. Six replications were made for each treatment and the flasks were incubated at room temperature $\left(26\right.$ to $29^{\circ} \mathrm{C}$ ) on a shaker (G10 Gyrotary shaker, USA) at $160 \mathrm{rpm}$ for 5 days. At the end of incubation, the fungal dry weight was compared with the control.

\section{Molecular identification of the isolates}

Pure cultures of potential M. phaseolina antagonistic actinomycetes were grown in Starch casein broth until log phase (four days) and genomic DNA were isolated according to Bazzicalupo and Fani (1995). The amplification of 16S rDNA gene was done by using universal primer 1492R (5'-TACGGYTACCTTGTTACGACTT-3') and 27F (5'- AGAGTTTGATCMTGGCTCAG-3') as per the conditions described by Pandey et al. (2005). The PCR product was sequenced at Macrogen Inc. Seoul, Korea. The sequences obtained were compared with those from the GenBank using the BLAST program (Altschul et al., 1990); aligned using the Clustal W software (Thompson et al., 1997) and phylogenetic trees inferred using the neighbor-joining method (Saitou and Nei, 1987).
Bootstrap analysis was performed to estimate statistical stability of the branches in the cluster with 1000 replicates using MEGA version 4 program (Tamura et al., 2007)

\section{Statistical analysis}

All the greenhouse experiments were arranged in completely randomized block design with six replications. The data were subjected to analysis of variance (ANOVA) (Genstat 10.1 version 2007, Lawes Agricultural Trust, Rothamsted Experimental Station) to evaluate the efficiency of the biocontrol agent's application in the greenhouse studies. Significance of differences between the treatment means was tested at $\mathrm{P}=0.01$ and 0.05 .

\section{RESULTS}

\section{Actinomycetes, bacterial and fungal population in the herbal vermicomposts}

No actinomycete was found in the compost prepared from Datura foliage, while all the other vermicomposts contained actinomycetes in the range of 6.3 to $7.7 \log 10$ (CFU) populations with an exception of tobacco compost, which contained only 2.0 Log10 populations (Table 1 ). 
Table 2. The eight most potential antagonistic actinomycetes against $M$. phaseolina, based on their different in vitro biocontrol and PGP traits.

\begin{tabular}{|c|c|c|c|c|c|c|}
\hline \multirow{2}{*}{ Isolate } & \multirow{2}{*}{$\begin{array}{l}\text { \% Inhibition } \\
\text { against MP }\end{array}$} & \multicolumn{4}{|c|}{ Production scale for } & \multirow{2}{*}{ IAA $\left(\mu \mathrm{g} \mathrm{ml}^{-1}\right)$} \\
\hline & & Sid $^{*}$ & Chit $^{\star}$ & Prot $^{\star}$ & $\mathrm{HCN}^{*}$ & \\
\hline CAI-17 & 70 & 2 & 0 & 3 & 3 & 0.34 \\
\hline CAI-21 & 63 & 1 & 0 & 3 & 3 & 1.13 \\
\hline CAI-26 & 60 & 2 & 1 & 4 & 3 & 1.17 \\
\hline CAI-68 & 73 & 3 & 0 & 4 & 2 & 0.22 \\
\hline CAI-78 & 50 & 0 & 0 & 2 & 2 & 0.95 \\
\hline KAI-26 & 63 & 3 & 2 & 3 & 1 & 0.4 \\
\hline KAI-27 & 63 & 1 & 2 & 0 & 2 & 0.47 \\
\hline MMA-32 & 55 & 3 & 1 & 2 & 2 & 4.66 \\
\hline
\end{tabular}

$\mathrm{MP}=$ Macrophomina phaseolina $\mathrm{CAI}=$ Compost actinomycete isolate; $\mathrm{KAI}=$ Karnataka actinomycete isolate; $\mathrm{MMA}=\mathrm{Masala}$ mitti actinomycete; Sid = Siderophore; Chit = Chitinase; Prot = Protease; HCN = Hydrocyanic Acid; IAA = Indole acetic acid; ${ }^{*}=$ rating scale for siderophore, chitinase, cellulose, lipase, protease and HCN were as follows: $0=$ Negative; $1=$ Positive; $2=1$ to $3 \mathrm{~mm} ; 3=4$ to $6 \mathrm{~mm} ; 4=>$ $6 \mathrm{~mm}$

The bacterial and fungal populations were found in the range of 7.4 to 9.3 and 6.3 to 7.3 Log10 values, respectively (Table 1). Maximum diversity of actinomycetes, bacteria and fungal population were found in vermicomposts prepared with Chrysanthemum, Oleander and Pongamia, respectively (Table 1). A total of 137 actinomycetes, the most prominent ones (the ones which were found abundantly, produced pigments and inhibited the adjacent colonies) in the SCA plate, were isolated and further screened for their antagonistic potential against M. phaseolina by in vitro dual-culture assay.

\section{In vitro biocontrol and plant growth promoting attributes of the actinomycetes}

Of the 137 actinomycete isolates studied for their biocontrol trait, only 79 of them were found to have the antagonistic potential against $M$. phaseolina. When the eight most potential antagonistic actinomycetes [compost actinomycete isolate; CAl-17, CAl-21, CAl-26, CAl-68, CAI-78, Karnataka actinomycete isolate; KAI -26, KAl-27 and Masala Matti actinomycete (MMA) -32; all originated from 25 different herbal vermicomposts] were evaluated further for their biocontrol and plant growth promoting traits, all the eight isolates produced HCN and IAA (MMA32 produced highest IAA; $4.66 \mu \mathrm{g} \mathrm{ml}-1$ ), seven isolates produced both siderophore (except CAI-78) and protease (except KAI-27) and four (CAI-26, KAI-26, KAI-27 and MMA-32) isolates produced chitinase (Table 2).

\section{In vivo antifungal activity by blotter paper assay}

When all the eight actinomycete isolates were evaluated for their in vivo antifungal potential against M. phaseolina by blotter paper assay, neither charcoal-rot disease symptoms (rating 0 in 0 to 4 visual rating scale) nor root infections (0\%) were observed in the KAl-26 and KAl-27treated sorghum roots, whereas very little disease symptoms (rating 1 to 2 ) and lesser root infection (47 to $77 \%$ lesser than the control) were observed in the other actinomycete-treated sorghum roots (Figure 1).

\section{Evaluation of actinomycetes in greenhouse conditions}

The isolates were further evaluated for their in vivo antagonistic potential against $M$. phaseolina in green house on sorghum crop. Root length was found greater in $6 / 8$ isolates (except CAI-68 and CAI-78), the maximum being found in two isolates namely $174 \mathrm{~cm}$ in CAl-17 and 171 $\mathrm{cm}$ in CAI-26, compared to $150 \mathrm{~cm}$ in the control plant roots (Table 3 ). All the eight isolates increased both sorghum shoot biomass (28 to $53 \%$ ) and root biomass (5 to $21 \%$ ) over the control (Table 3). The highest increase of both shoot and root biomass ( 45 and $21 \%$, respectively) was found in CAI-26 (Table 3). Shoot root ratio was found higher in all the isolates, ranging 3.01 to 3.74 compared to 2.74 in the control (Table 3). No negative effect was found in any of the isolates.

In order to confirm the PGP traits, all the isolates were further evaluated in green house but without inoculating M. phaseolina on sorghum crop. All the eight isolates increased sorghum shoot biomass by 10 to $34 \%$; however, only six isolates increased more than 15\% biomass (except CAI-26 and KAl-27) (Table 4). Root biomass was also found increased in all eight isolates (up to $57 \%$ ) but only five isolates (CAl-17, CAl-21, CAI-26, CAI-78 and MMA-32) increased more than 14\% (Table 4). Root length (except CAI-68), root volume (except CAI- 


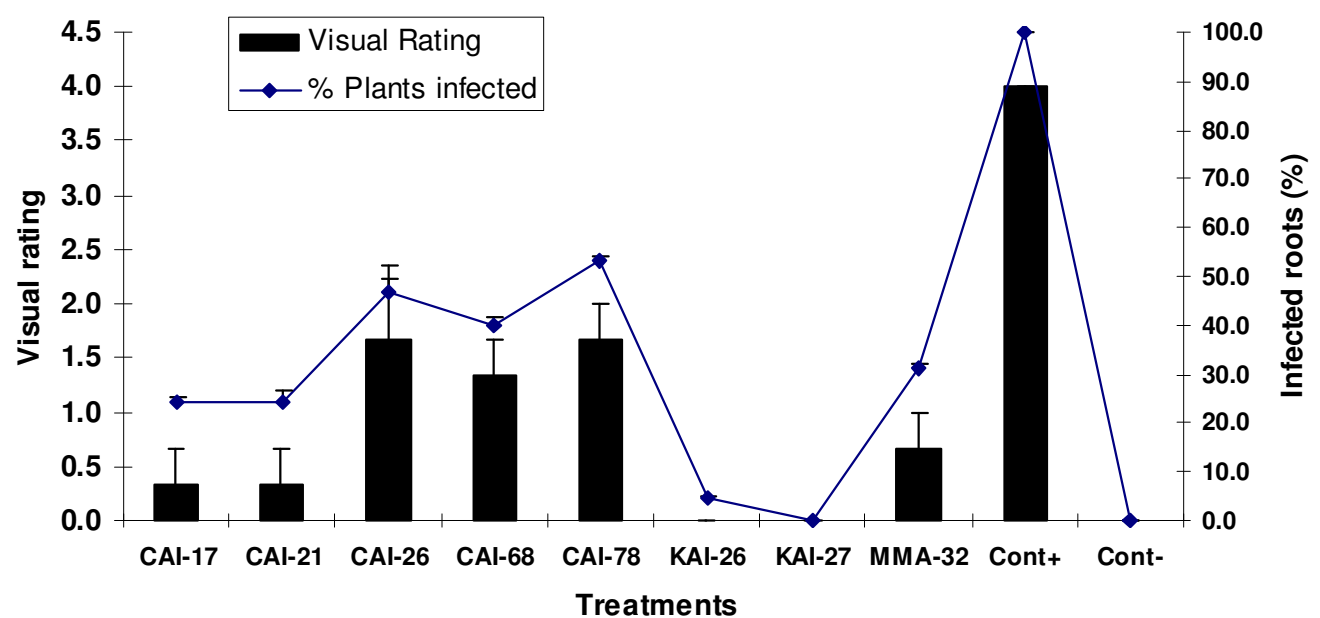

Figure 1. Influence of the eight most potential actinomycete isolates on Macrophomina phaseolina by blotting paper assay (Gopalakrishnan et al., 2011).

Table 3. Evaluation of the eight most potential actinomycetes for their antagonistic potential against Macrophomina phaseolina, in sorghum under green house conditions.

\begin{tabular}{lcccccc}
\hline \multirow{2}{*}{ Treatment } & $\begin{array}{c}\text { Root length } \\
(\mathbf{c m})\end{array}$ & $\begin{array}{c}\text { Root weight } \\
(\mathbf{g})\end{array}$ & $\begin{array}{c}\text { Shoot weight } \\
(\mathbf{g})\end{array}$ & $\begin{array}{c}\text { Shoot root } \\
\text { ratio }\end{array}$ & \multicolumn{2}{c}{ \% Increase over control } \\
\cline { 6 - 7 } & & & Shoot weight & Root weight \\
\hline CAI-17 & 174 & 0.86 & 2.58 & 3.01 & 28 & 14 \\
CAI-21 & 159 & 0.84 & 3.08 & 3.74 & 53 & 12 \\
CAI-26 & 171 & 0.91 & 2.92 & 3.24 & 45 & 21 \\
CAI-68 & 136 & 0.79 & 2.9 & 3.7 & 44 & 5 \\
CAI-78 & 137 & 0.81 & 2.82 & 3.52 & 40 & 8 \\
KAI-26 & 167 & 0.83 & 2.88 & 3.5 & 43 & 10 \\
KAI-27 & 169 & 0.85 & 2.8 & 3.3 & 39 & 13 \\
MMA-32 & 153 & 0.85 & 2.68 & 3.17 & 33 & 13 \\
Control & 150 & 0.75 & 2.01 & 2.74 & & \\
Mean & 159 & 0.83 & 2.74 & 3.35 & 40 & 11 \\
SE \pm & $15.5^{* * *}$ & $0.061^{* * *}$ & $0.195^{*}$ & $0.220^{* * *}$ & & \\
LSD (5\%) & 4.4 & 0.173 & 0.554 & 0.624 & & \\
CV\% & 23 & 17 & 17 & 17 & & \\
\hline
\end{tabular}

Values are means of six replications and data calculated per plant after 60 DAS. ${ }^{*}=$ statistically significant at $0.05 ;{ }^{* * *}=$ statistically significant at $<0.001 ; \mathrm{SE}=$ standard error; $\mathrm{LSD}=$ least significant difference; $\mathrm{CV}=$ coefficient of variance.

17) and shoot root ratio (except CAI-21, CAI-26 and MMA-32) were also found greater in comparison to the control (Table 4). Among the eight actinomycetes, MMA32 increased all the parameters by at least $25 \%$, that is shoot dry mass $(27 \%)$, root dry mass $(57 \%)$, root length $(60 \%)$ and root volume (64\%), over the control (Table 4).

\section{Effect of culture filtrates of actinomycetes on fungal pathogens}

Culture filtrates of three promising actinomycetes, CAI21, CAI-26 and MMA-32, were partitioned against ethyl acetate, and the resultant organic and aqueous fractions were evaluated against $M$. phaseolina. Organic fractions of CAI-21, CAI-26 and MMA-32, at $0.5 \%$ concentration inhibited the growth of $M$. phaseolina by 55 to $65 \%$, whereas aqueous fractions enhanced the growth of the fungus by 33 to $64 \%$, over the control (Figure 2).

\section{Molecular identification of the actinomycete isolates}

In order to determine the identity of the eight potential PGP and antagonistic (against $M$. phaseolina) actinomycetes, its $16 \mathrm{~S}$ rDNA was sequenced and analyzed. A neighbor joining dendrogram was generated using the sequences from the eight actinomycetes (1400 bp) and 
Table 4. Evaluation of the eight most potential actinomycetes for their plant growth promoting potential, in sorghum under green house conditions.

\begin{tabular}{|c|c|c|c|c|c|c|c|c|c|}
\hline \multirow{2}{*}{ Treatment } & \multirow{2}{*}{$\begin{array}{c}\text { Shoot weight } \\
\text { (g) }\end{array}$} & \multirow{2}{*}{$\begin{array}{c}\text { Root weight } \\
\text { (g) }\end{array}$} & \multirow{2}{*}{$\begin{array}{c}\text { Root length } \\
(\mathrm{cm})\end{array}$} & \multirow{2}{*}{$\begin{array}{c}\text { Root volume } \\
\left(\mathrm{cm}^{-3}\right)\end{array}$} & \multirow{2}{*}{$\begin{array}{c}\text { Shoot root } \\
\text { ratio }\end{array}$} & \multicolumn{4}{|c|}{$\%$ Increase over control } \\
\hline & & & & & & Shoot weight & Root weight & Root length & Root volume \\
\hline CAI-17 & 6.67 & 0.75 & 431 & 14.6 & 9.0 & 19 & 19 & 7 & 0 \\
\hline CAI-21 & 7.36 & 0.88 & 421 & 17 & 8.6 & 31 & 40 & 4 & 16 \\
\hline CAI-26 & 6.16 & 0.81 & 575 & 21.2 & 7.7 & 10 & 29 & 42 & 45 \\
\hline CAI-68 & 6.44 & 0.64 & 405 & 15.5 & 10.5 & 15 & 2 & 0 & 6 \\
\hline CAI-78 & 6.52 & 0.72 & 611 & 19.2 & 9.8 & 16 & 14 & 51 & 31 \\
\hline KAI-26 & 7.50 & 0.67 & 472 & 16.1 & 12.2 & 34 & 6 & 17 & 10 \\
\hline KAI-27 & 6.25 & 0.68 & 483 & 16 & 8.9 & 11 & 8 & 20 & 10 \\
\hline MMA-32 & 7.14 & 0.99 & 647 & 23.9 & 7.2 & 27 & 57 & 60 & 64 \\
\hline Control & 5.61 & 0.63 & 404 & 14.6 & 8.9 & & & & \\
\hline Mean & 6.69 & 0.74 & 486 & 17.3 & 9.5 & 21 & 20 & 23 & 20 \\
\hline SE \pm & $0.256^{\mathrm{NS}}$ & $0.063^{* *}$ & $65.17^{*}$ & $2.490^{N S}$ & $0.851^{* * *}$ & & & & \\
\hline LSD (5\%) & 0.728 & 0.181 & 185.13 & 7.074 & 2.420 & & & & \\
\hline CV\% & 9 & 21 & 33 & 35 & 22 & & & & \\
\hline
\end{tabular}

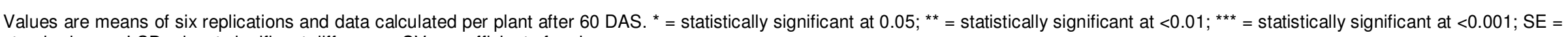
standard error; LSD = least significant difference; $C V=$ coefficient of variance.

representative sequences from the databases. Phylo-genetic analysis of $16 \mathrm{~S}$ rDNA sequences of the eight actinomycete isolates matched with Streptomyces but it was not possible to identify up to species level (Figure 3).

\section{DISCUSSION}

Vermicomposts have been widely used in agriculture not only for its beneficial effects on soil structure and biota but also for its ability to inhibit plant pathogens, for example, Asciutto et al. (2006) reported that vermicompost at $25 \%$ controlled Rhizoctonia solani that causes damping off in Patience-plant (Impatiens walleriana). Hence, in the present investigation, various herbal vermicomposts were screened for isolating antagonistic actinomycetes against $M$. phaseolina. Of the 137 actinomycetes obtained from the herbal vermicomposts, 79 (58\%) of them were found to have the antagonistic potential (in the dual-culture assay) against $M$. phaseolina. This inhibition could be due to the production of hydrolytic enzymes or antibiotics by the actinomycetes which were disseminated through the media. Therefore, it can be concluded that production of antifungal substances may be involved in the inhibition of hyphal growth of fungal pathogens, as there was no direct contact between fungal pathogens and actinomycete colonies in the dual-culture assay. The eight most promising isolates (CAl-17, CAl-21, CAl-26, CAl68, CAI-78, KAI-26, KAI-27 and MMA-32) (Table 2) were further characterized for siderophore, HCN, IAA, chitinase and protease. Siderophores are usually produced by various soil microbes including actinomycetes to bind $\mathrm{Fe}^{3+}$ from the environment and make it available for its own growth; plants also utilize these as an iron source (Wang et al., 1993). Actinomycetes (Streptomyces spp.) isolated from rhizosphere soil have been reported to produce siderophores and inhibit the growth of phytopathogens (Tokala et al., 2002). Actinomycetes found in the rhizosphere, the need to compete with other rhizosphere plant pathogens for iron, hence competition for iron is also a possible mechanism to control the phytopathogens. HCN production is also reported to play a role in disease suppression (Wei et al., 1991), for instance, Haas et al. (1991) reported HCN production by strains of Pseudomonas fluorescens that helped in suppression of black root rot of tobacco. In the present investigation, 


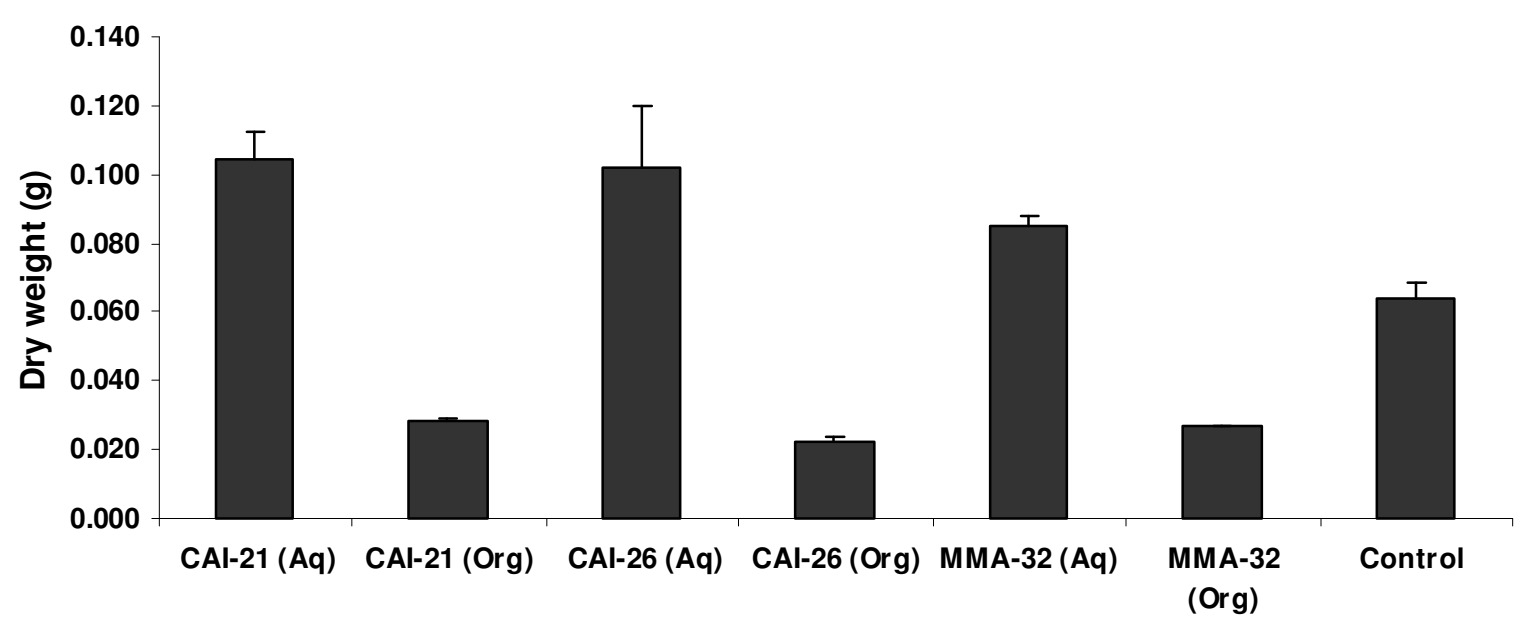

Actinomycetes

Figure 2. The effect of organic (Org) and aqueous ( $\mathrm{Aq}$ ) fractions (of solvent partitioning) of the culture filtrates of actinomycetes (CAI-21, CAl-26 and MMA-32) on the growth of Macrophomina phaseolina, compared to the control (Gopalakrishnan et al., 2011).

all the eight antagonistic actinomycetes produced $\mathrm{HCN}$, while seven of them produced siderophore (except CAI78). Hence, it can be concluded that the isolates have good biocontrol potential (Table 2).

IAA-producing microorganisms are known to promote root elongation and plant growth (Patten and Glick, 2002). By producing the plant hormones, microorganisms stimulate plant growth in order to increase the production of plant metabolites which can be beneficial for their growth. In the present study, all the eight actinomycetes produced IAA (Table 2), suggesting that these isolates could be used for plant growth promotion. Of the eight isolates studied, MMA-32 produced the highest IAA (4.66 $\mu \mathrm{g} \mathrm{ml}^{-1}$ ) and thus can be exploited by the host plants. In the present study, it was also noticed that seven actinomycetes produced protease (except KAI-27) but only four produced chitinase (CAI-26, KAl-26, KAI-27 and MMA-32). Protease and chitinase-producing microorganisms play an important role in the decomposition of organic matter, nutrient mineralization and promoting plant growth in addition to act as biocontrol agents on protein cell wall-bearing pathogens such as Phytophthora and Pythium spp. (Lima et al., 1998). When the eight potential actinomycete isolates, against $M$. phaseolina in the dual culture assay were evaluated by blotter paper assay on sorghum plants, KAI-26 and KAl-27 completely inhibited the growth of $M$. phaseolina (no infection or charcoal-rot disease symptoms were found in the sorghum roots), while all the other isolates inhibited the fungus greatly (47 to $77 \%$ lesser infection compared to the control) (Figure 1). In the green house experiment, where the eight isolates were evaluated for their antagonistic and PGP potential on sorghum plants, shoot dry mass (up to $34 \%$ increase), root dry mass (up to $57 \%$ increase), root length (up to $60 \%$ increase) and root volume (up to $64 \%$ increase) were found higher in comparison with the control (Table 4). The mechanism by which the actinomycetes enhanced sorghum seedlings vigour could be its PGP attributes (IAA and siderophore production). As in the present study, all the actinomycetes isolates produced IAA and siderophore (except CAl-78) (Table 2). Root colonization is very much essential to deliver the beneficial microbes at the right place and time on the root, as poor root colonization may result in decreased biocontrol activity (Schippers et al., 1987). Ryder and Jones (1993) reported that the ability of the antagonistic microorganisms to maintain a sufficient population density in the rhizosphere for a sufficient length of time is critical for the success of any biocontrol method. Lugtenberg and Dekkers (1999) suggested that selection of any potent strain useful for biocontrol must be based on the rhizosphere competence, antagonistic ability and the root-colonizing ability.

Observation on root colonization was not done in this study; however, upon looking at the data on biomass of plants (up to $34 \%$ increase in shoot mass and up to $64 \%$ increase in root mass in actinomycete inoculated treatments) it can be hypothesized that actinomycetes might have multiplied and colonized on sorghum roots, a property desirable for survival and functioning of a biocontrol agent. The eight actinomycetes used in this study were apparently well adapted to the sorghum rhizosphere environment, as it not only controlled the charcoal-rot disease in sorghum but also enhanced the plant growth. Adhikari et al. (2001) reported that bacterial strains isolated from rice rhizosphere have the potential to control the seedling disease of rice (caused by Achlya klebsiana and Pythium spinosum) and to promote plant growth. Similar results were obtained with the plant growth-promoting Bacillus subtilis $\mathrm{BN} 1$ from the 


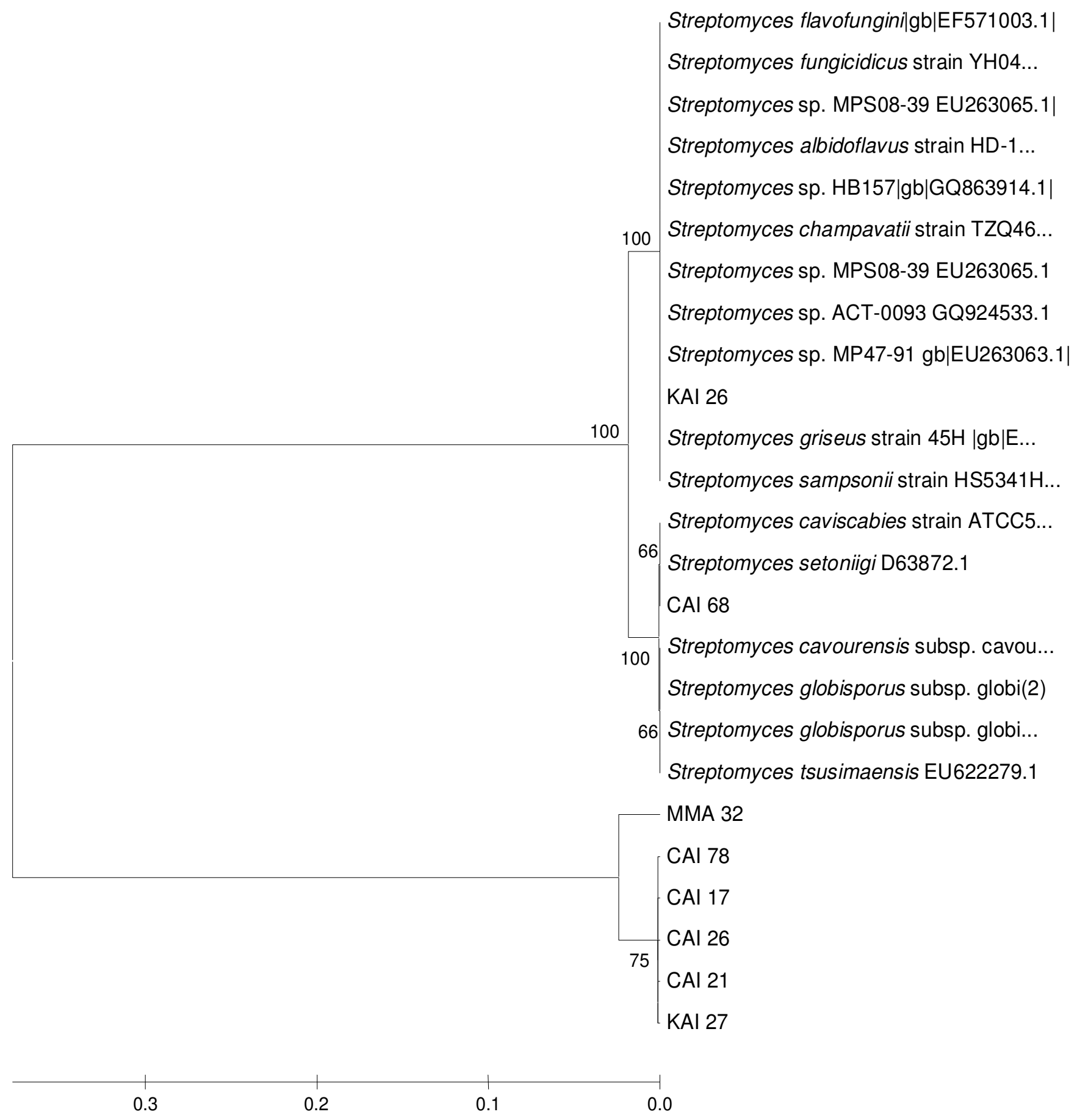

Figure 3. Phylogenetic relationship between actinomycete isolates and representative species based on full length $16 \mathrm{~S}$ rDNA sequences constructed using the neighbor-joining method. The scale bar indicates the genetic distance and the numbers shown next to each node indicate the bootstrap values from 500 replications (Gopalakrishnan et al., 2011).

rhizospheres of chir pine (Pinus roxburghii) (Singh et al., 2008), fluorescent Pseudomonas $\mathrm{GRC}_{2}$ from potato rhizosphere (Gupta et al., 2002) and Pseudomonas chlororaphis SRB 127 from sorghum rhizosphere (Das et al., 2008) that showed strong antagonistic effect against M. phaseolina, a charcoal-rot pathogen of peanut and sorghum. However, there were no reports of actinomycetes isolated from vermicompost on $\mathrm{M}$. phaseolina. The organic fractions of the culture filtrates (ethyl acetate extract) of the three promising actinomycetes, CAI-21, CAI-26 and MMA-32, at $0.5 \%$ inhibited the growth of $M$. phaseolina by 55 to $65 \%$, whereas the aqueous fractions 
of the culture filtrates enhanced the growth of the pathogen by 33 to $64 \%$ (Figure 2). Based on these results, it can be concluded that the organic fractions of the culture filtrates contain secondary metabolites that are capable of inhibiting the pathogen, while the aqueous fractions contain metabolites that are capable of enhancing the growth of the pathogen. Remya and Vijaykumar (2008) reported that ethyl acetate extract of Streptomyces strain RM 42 showed maximum activity against E. coli, followed by Salmonella typhi, Candida albicans and $B$. subtilis. The culture filtrates of Streptomyces hygroscopicus were found to inhibit $S$. rolfsii and Colleotrichum gloeosporioides, which cause collar rot and anthracnose, respectively in a wide variety of crops (Prapagdee et al., 2008).

Phylogenetic analysis of $16 \mathrm{~S}$ rDNA sequences of the eight $M$. phaseolina antagonistic actinomycetes showed that all the isolates belong to the genus Streptomyces but it was not possible to identify up to the species level (Figure 3). Streptomyces spp. has been shown to protect many crop plants against pathogenic fungi (Liu et al., 1996). For instance, $S$. hygroscopicus antagonized $R$. solani, the causal organism of pea root rot (Rothrock and Gottlieb, 1984) and Streptomyces spp. strain g10 exhibited strong antagonism towards Fusarium oxysporum f. sp. cubense, causal organism of wilt in banana (Getha et al., 2005). Streptomyces spp. were also found to control FOC, for example Streptomyces rochei and Streptomyces rimosus isolated from the chickpea rhizosphere were found to have antagonistic potential against FOC (Bashar and Rai, 1994) and Streptomyces spp. isolated from national parks in Kenya were shown to have antifungal activity against FOC (Nonoh et al., 2010). The actinomycetes present in the rhizosphere soil that are antagonistic against the plant pathogens Alternaria brassicicola, Collectotrichum gloeosporioides, F. oxysporum, Penicillium digitatum and $S$. rolfsii have been shown to belong to Streptomyces spp. (Khamna et al., 2009).

The present study was successful in selecting effective isolates of actinomycetes, from herbal vermicomposts, that can be a useful component of integrated disease management. All the eight actinomycetes could be used as biocontrol agents for the control of charcoal-rot of sorghum. The broad range of antifungal activity of the eight antagonistic actinomycetes demonstrates the multiple mechanisms of action (antibiosis, HCN, siderophore, IAA and cell wall degrading enzymes) (Table 2) and hence may involve more than one antifungal metabolite. Ethyl acetate extract of the culture filtrates of CAI-21, CAl-26 and MMA-32 contains secondary metabolites that are capable of inhibiting $M$. phaseolina. Hence, these actinomycetes are likely to be the potential candidates for discovery of novel secondary metabolites for various biocontrol applications. Determination of the exact mechanisms of action of these biocontrol agents can assist in furthering the use of ecofriendly bio-fungicides.

\section{ACKNOWLEDGEMENTS}

We thank the National Bureau of Agriculturally Important Microorganisms for providing financial support. We also thank all the staff of the biocontrol unit of ICRISAT, including M/s P.V.S. Prasad, P. Manohar, B. Nagappa and $M$. Satyam for their significant inputs in the laboratory and greenhouse house studies.

\section{REFERENCES}

Adhikari TB, Joseph CM, Yang G, Phillips DA, Nelson LM (2001). Evaluation of bacteria isolated from rice for plant growth promotion and biological control of seedling disease of rice. Can. J. Microbiol. 47: $916-924$.

Altschul SF, Gish W, Miller W, Myers EW, Lipman DJ (1990). Basic local alignment search tool. J. Mol. Biol. 215: 403-410.

Asciutto K, Rivera MC, Wright ER, Morisigue D, Lopez MV (2006). Effect of vermicompost on the growth and health of Impatiens wallerana. Int. J. Exp. Bot. 75: 115-123.

Bashar MA, Rai B (1994). Antagonistic potential of root region microflora of chickpea against Fusarium oxysporum f. sp. ciceri. Bangl. J. Bot. 23: 13-19.

Bazzicalupo M, Fani R (1995). The use of RAPD for generating specific DNA probes for microorganisms. In: Clap JP (ed.). Methods in Molecular Biology, Species Diagnostic Protocols: PCR and other Nucleic Acid Methods. Humana Press Inc, Totowa NJ, pp. 122-124.

Bhattacharya A, Chandra S, Barik S (2009). Lipase and protease producing microbes from the environment of sugar beet field. Ind. J. Agric. Biochem. 22: 26-30.

Bhattacharya G, Siddiqui KAI, Chakraborty S (1994). The toxicity of phaseolinone to mice. Ind. J. Pharmacol. 26: 121-125.

Das IK, Indira S, Annapurna A, Prabhakar S, Seetharama N (2008). Biocontrol of charcoal-rot in sorghum by fluorescent Pseudomonads associated with the rhizosphere. Crop Prot. 27: 1407-1414.

Edwards CA (1998). The use of earthworms in processing organic wastes into plant growth media and animal feed protein. In: Earthworm Ecology (ed.) Edwards CA, CRC press: Boca Raton, Florida. pp. 327-354.

Getha K, Vikineswary S, Wong WH, Seki T, Ward A, Goodfellow M (2005). Evaluation of Streptomyces spp. strain g10 for suppression of Fusarium wilt and rhizosphere colonization in pot-grown banana plantlets. J. Ind. Microbiol. Biotechnol. 32: 24-32.

Gopalakrishnan S, Kannan IGK, Alekhya G, Humayun P, Meesala SV, Kanala D (2010). Efficacy of Jatropha, Annona and Parthenium biowash on Sclerotium rolfsii, Fusarium oxysporum f. sp. ciceri and Macrophomina phaseolina, pathogens of chickpea and sorghum. Afr. J. Biotechnol. 9: 8048-8057.

Gupta CP, Dubey RC, Maheswari DK (2002). Plant growth enhancement and suppression of Macrophomina phaseolina causing charcoal-rot of peanut by fluorescent Pseudomonas. Biol. Fertil. Soil. 35: 399-405.

Haas K, Keel C, Laville J, Maurhofer M, Oberhansli TF, Schnider U, Voisard C, Wuthrich B, Defago G (1991). Secondary metabolites of Pseudomonas fluorescens strain $\mathrm{CHAO}$ involved in the suppression of root diseases. In: Hennecks H, Verma DPS (eds.), Advances in Molecular Genetics of Plant-Microbe Interactions, Interlaken, Switzerland. pp. 450-456.

Hirano S, Nagao N (1988). An improved method for the preparation of colloidal chitin by using methanesulfonic acid. Agric. Biol. Chem. 52: 2111-2112

Khamna S, Yokota A, Lumyong S (2009). Actinomycetes isolated from medicinal plant rhizosphere soils: diversity and screening of antifungal compounds, indole-3-acetic acid and siderophore production. World J. Microbiol. Biotechnol. 25: 649-655.

Lima LHC, Marco JL, Felix CR (1998). Enzimas hidroliticas envolvidas no controle biologico por miciparasitisma. Controle biologico. Jaguraiuna. In: Melo IS, Azevedo JL (eds.), Controle Biologico. Jaguriuna: EMBRAPA-Meio Ambiente. 11: 263-304. 
Liu D, Anderson NA, Kinkel LK (1996). Selection and characterization of strains of Streptomyces suppressive to the potato scab pathogen. Can. J. Microbiol. 4: 487-502.

Lorck H (1948). Production of hydrocyanic acid by bacteria. Physiol. Plant. 1: 142-146.

Lugtenberg BJJ, Dekkers LC (1999). What makes Pseudomonas bacteria rhizosphere competent? Environ. Microbiol. 1: 9-13.

Nath G, Singh K (2009). Utilization of vermiwash potential on certain summer vegetable crops. J. Central Eur. Agric. 10: 417-426.

Nene YL, Haware MP, Reddy MV (1981). Chickpea diseases: resistance-screening techniques, Infor. Bull. ICRISAT, 10: 5-7.

Nonoh JO, Lwande W, Masiga D, Herrmann R, Presnail JK, Schepers E, Okech MA, Bagine R, Mungai P, Nyende AB, Boga HI (2010). Isolation and characterization of Streptomyces spp. with antifungal activity from selected national parks in Kenya. Afr. J. Microbiol. Res. 4: 856-864.

Pandey P, Kang SC, Maheswari DK (2005). Isolation of endophytic plant growth-promoting Burkholderia spp. MSSP from root nodules of Mimosa pudica. Curr. Sci. 89: 177-180.

Patten CL, Glick BR (1996). Bacterial biosyntehsis of indole-3-acetic acid. Can. J. Microbiol. 42: 207-220.

Patten CL, Glick BR (2002). Role of Pseudomonas putida in indole acetic acid in development of host plant root system. Appl. Environ. Microbiol. 68: 3795-3801.

Perner H, Schwarz D, George E (2006). Effect of mycorrhizal inoculation and compost supply on growth and nutrient uptake of young leek plants grown on peat-based substrates. Hort. Sci. 4: 628632.

Postma J, Montanari M, Van den Boogert PHJF (2003). Microbial enrichment to enhance disease suppressive activity of compost. Eur. J. Soil Biol. 39: 157-163.

Prabha ML (2009). Waste management by vermin-technology. Indian J. Environ. Prot. 29: 795-800.

Prapagdee B, Kuekulvong C, Mongkolsuk S (2008). Antifungal potential of extracellular metabolites produced by Streptomyces hygroscopcius against phytopathogenic fungi. Int. J. Biol. Sci. 4: 330-337.

Remya M, Vijayakumar R (2008). Isolation and characterization of marine antagonistic actinomycetes from west coast of India. Facta. Univ. Med. Biol. 15: 13-19.

Rothrock CS, Gottlieb D (1984). Role of antibiosis in antagonism of Streptomyces hygroscopicus var. geldanus to Rhizoctonia solani in soil. Can. J. Microbiol. 30: 1440-1447.

Ryder MH, Jones DA (1993). Biological control of crown gall. In: Hornby D (ed.), Biological Control of Soil-Borne Plant Pathogens, CAB international, UK. pp. 45-63.

Saitou N, Nei M (1987). The neighbor-joining method: a new method for reconstructing phylogenetic trees. Mol. Biol. Evol. 4: 406-425.
Schippers B, Baker AW, Bakker PAHM (1987). Interactions of deleterious and beneficial rhizosphere microorganisms and the effect of cropping practices. Annu. Rev. Phytopathol. 25: 339-358.

Schwyn B, Neilands J (1987). Universal chemical assay for the detection and determination of siderophores. Anal. Biochem. 160: 4756.

Singh N, Pandey P, Dubey RC, Maheshwari DK (2008). Biological control of root rot fungus Macrophomina phaseolina and growth enhancement of Pinus roxburghii by rhizosphere competent Bacillus subtilis BN1. World J. Microbiol. Biotechnol. 24: 1669-1679.

Suthar S, Choyal R, Singh R, Sudesh (2005). Stimulatory effect of earthworm body fluid on seed germination and seedlings growth of two legumes. J. Phytol. Res. 1: 219-222.

Tamura K, Dudley J, Nei M, Kumar S (2007). MEGA4: Molecular evolutionary genetics analysis (MEGA) software version 4.0. Mol. Biol. Evol. 24: 1596-1599.

Thompson JD, Gibson TJ, Plewniak F, Jeanmougin F, Higgins DG (1997). The clustalX windows interface: flexible strategies for multiple sequence alignment aided by quality analysis tools. Nucleic Acid. Res. 25: 4876-4882.

Tokala RK, Strap JL, Jung CM, Crawford DL, Salove MH, Deobald LA, Bailey JF, Morra J (2002). Novel plant-microbe rhizosphere interaction involving Streptomyces lydicus WYEC108 and the pea plant (Pisum sativum). Appl. Environ. Microbiol. 68: 2161-2171.

Wang Y, Brown HN, Crowley DE, Szaniszlo P (1993). Evidence for direct utilization of a siderophore, ferrioxamine $B$, in axenically grown cucumber. Plant Cell Environ. 16: 579-585.

Wei G, Kloepper JW, Sadik T (1991). Induction of systemic resistance of cucumber to Colletotrichum orbiculare by select strains of plant growth-promoting rhizobacteria. Phytopathology, 81: 508-512.

Wyllie TD (1998). Charcoal-rot. In: Sinclair JB, Backman PA (eds.) Compendium of Soybean Diseases, $3^{\text {rd }}$ Edn. APS Press, St. Paul, MN. pp. 114-118. 